\title{
The Characteristic of Rhetoric Discourse in Pilkada Political Advertisement
}

\author{
Fahrudin Eko Hardiyanto ${ }^{1}$, Fathur Rokhman², Ida Zulaeha ${ }^{3}$, Haribakti Mardikantoro $^{4}$ \\ ${ }^{1}$ Universitas Pekalongan, Pekalongan, Indonesia \\ 2,3,4 Universitas Negeri Semarang, Indonesia \\ ${ }^{1}$ Corresponding email: fahrudineko@gmail.com
}

\begin{abstract}
Political advertisements have been inseparable from The Regional Head Election 2015 in Central Java. There were many political advertisements presented by the candidates of regional head in diverse, likewise the varied in chracteristics. The objectives of this research is to analyze the characteristic of rethoric discourse Pilkada. The discussed problem is what the characteristics of rethoric discourse in Pilkada political advertisement 2015. Techniques used in this research were observation and note scrutinize. It was on a piece of advertisement discourse which be expected as the statements of rethoric discourse Pilkada political advertisement values. Based on the results of Pilkada political advertisement programmatic analysis, it can be found that the characteristics of Pilkada political advertisement discourse based on the rhetorical study are formed as ethos, pathos, and logos. Within the ethos aspect, the chatacteristics of pilkada advertisement formed education technique to the public, good personality from the candidate, and the credibility of public to the leader candidate. In the pathos aspect, there are the characteristics of emphaty, symphaty, the change booster, the emotional instigator while on the logos aspect, it is manifested in logic discourse persuasion, and there is the use of parable and proverb.
\end{abstract}

Key words: characteristic, rhetoric, discourse, pilkada advertisement

\section{Introduction}

The democracy of The Regional Head Election (Pilkada) on 2015 has been held simultaneously in most parts of Indonesia, including in Central Java Province. There are 21 district and city. Each prospective regional leader takes advantage of campaign or balloting activities to attract public sympathy to support him through public service advertising such as banner or billboards campaigns. Prospective regional leaders also socialize the vision, mission, and programs to the public. The role and the whereabouts of political advertisements in this case determine the public support for the candidates for regional head.

Political advertising by Firmanzah (2007) has a decisive role in this process. One function of political advertising is to provide political education to the public audiences. Therefore, any political party or candidate pair of regional leaders in the elections (Pilkada) always presents an interesting thing as a campaign strategy.

Regent/ mayor candidates in their political advertisements seek to persuade the public by showing good credibility and good competence to be eligible. For that purpose, they use a fascinating rhetorical approach which contains beauty and dignified values.

Rhetoric becomes important to be studied, especially in the political election discourse. Since political advertising is an effective vehicle for candidates to build communication and education for the wider community, campaign contents contained on banners or billboards must not violate the principles of legal, social, religious, and beauty norms. The rhetoric on Pilkada political advertisements not only prioritizes the message to the audience, but also attention to the supporting aspects that can make the political advertisement can be received well by the audience and get a positive response both based on the content of advertising and delivery techniques. Both of these are characteristics of a good political advertisement. Aristotle (in Luhakay, 2007: 56) suggests that in an advertisement there is a rhetorical approach applied through three aspects of rhetoric namely ethos, pathos, and logos.

\section{Methods}

This study examines the characteristics of Pilkada political advertisement 2015 in Central Java. This research data formed a piece of political election which allegedly contained advertisement character with rhetorical approach and the content which is contained in baliho or banner of regent or mayor candidates in 21 regencies and cities in Central Java. Methods and techniques of data collection in this study was a scrutinized method with free gathering 
involving capable technique, recording techniques, and note techniques. Three stages of analysis used in this research were data reduction, data presentation, and picture of conclusion and verification.

Presentation of data is an assembly of information in a well-organized manner so that it is able to generate a picture of conclusions and actions through the analysis of text and context. Text analysis is a process of analyzing text data, the object of the study is the structure of the text about the vocabulary, sentence, proposition, and paragraphs to explain and interpret a text.

\section{Results and Discussion}

In the discourse on political advertisement of Regional Head Election of Central Java 2015, there are 3 characteristics of political advertisement of Regional Head Election which come from two things namely the form of political advertisement discourse of Pilkada based on rhetorical approach and the form of ad discourse based on its contents.

a. Characteristic of Political Advertisement of Regional Head Election Central Java 2015

Based on Lingual Form

Lingual form in political advertisement Pilkada Central Java 2015 which contains the characteristics of Pilkada political advertisement is the discourse of advertising in the form of phrases and sentences. The discourse of political advertisement in the form of a phrase can be categorized as follows.

1. Nominal Phrase (Indonesian Language)

One for Change, Amanah and Rahmatan Lil

Alamin; Leaders Who Serve and Protect;

2. Nominal Phrase (Javanese Language)

Bolo Dewe, Sedhulur Dewe; Ngayomi lan Ngayemi;

3. Verb phrases

Continue Development of Boyolali Pro Investment; Coblos Atine;

4. Adjective Phrase

Prosperous, Religious, Advancing; Prosperous, Independent; One Heart with Us; Semanak-Nyedulur; Makmur Rakyate;

In addition to the form of phrases and sentences, Pilkada political advertisement Central Java 2015 also found in the form of acronyms of self-nominated regional leaders who describe the name and a positive selfimage. Acronyms contained in political advertisement Pilkada Central Java in 2015 is short for a combination of letters or syllables or other parts as a reasonable word.

Here is the political campaign discourse elections Central Java 2015 in the form of acronyms. SEMAR (SEmangat Mendukung Arifin-Romi); DADI (Dukung Agung-afifuDIn); KARISMATIK (KAng RISwadi bersaMA nurbalisTIK); ASRI (Asip-aRIni); WALI (WidyAHiLmI); MANIS BERSYUKUR (MirnA NISa BERsama masYKUR); HEBAT (Hendi Bersama rakyAT); SIBAGUS (SIgit BersamA aGUS); MUKTI (Munjirin-ngesTI); JATI (JATmIkoMASud); NASIR JOS (NAtSIR-Joko Susanto); PASTI HARUM (PASangan sehaTI HARwantoMasykuri); SUKUN (SUmarto-KUNtum); ADA (Abu-DAsuri); NURANI (NURdin-ANIs); SUKO (SUgiyanto-joKO); AMAN TO (Agus fathurrahMAN-joko suprapTO); MAE (MAyaEko); SUPER SUMEH (Sarip-Usup, PEduli Rakyat. Sarip-Usup, seMoga bErkaH); HARJO (HARdi-JOko); HATI MULYA (HArTIniMULYAni); SI WINNER (Sigit-WINdarti beNER); dan HARUS (HARyanto-agUS).

b. Characteristic of Political Advertisement o Regional Head Election Central Java 2015 Based On Rethoric Approach (Sense)

In the political advertisement character of elections of Central Java 2015, 3 aspects of study were found. They are ethos, pathos, and logos aspects.

\section{Ethos}

Ethos aspects of political election discourse refers to an aspect which indicates that the candidates of regent/ mayor have extensive knowledge, trusted personality, and has an honorable status. The advertisement discourse displayed by the candidate pairs can convince and illustrate to the prospective voter audience that the candidate pair is a trustworthy person. For example about his politeness in communicating. By speaking, the three officials will easily launch their own ideology. The public can easily accept, support, and even believe in the ideology represented in the official's polite speech (Widyawari and I. Zulaekha, 2016: 5)

The form of Pilkada political discourse is based on the ethos aspect rhetoric approach, namely: One for Change, Amanah and Rahmatan Lil Alamin; With the People Building Great Pemalang; Together Mbangun Pekalongan, Faster and Benefit; Sithik Omonge, Akeh Kerjone; Continue Development of Boyolali Pro Investment; Leaders Who Serve and Protect; Bolo Dewe, Sedhulur Dewe; Brayan 
Urip; Prosperous, Religious, Advancing; Prosperous, Independent; Makmur Rakyate; $A D A$ for Blora Sejahtera; Sehat with Us; Semanak-Nyedulur; Guyub Rukun Mbangun Kebumen; Coblos Atine; Work Wholeheartedly. Building Wonosobo Safe and Prosperous; Ngayomi lan Ngayemi; and Harjo are Friends, People's Choice

Herrick (2001: 89) in his book The History and Theory of Rhetoric, explains that the ethos aspect of rhetoric means a persuasive potential for character and credibility personal. According to Aristotle (in Maarif, 10-11) that the indicator of a discourse belongs to the rhetoric of ethical aspect of ethos includes three things: phronesis, arete, and eunoia.

Ethos contained in political ads Pilkada classification embraces the following aspects.

\section{1) Phronesis}

Phronesis is a discourse that conveys a good statement, a statement that is not only already known by the general public, but also something that can increase the audience and can be done by others.

Phronesis elements on the ethos aspect contained in political election 2015 election is illustrated through the following discourse.

\section{(1) "BERSAMA RAKYAT MEMBANGUN PEMALANG HEBAT"}

The message conveyed through this advertisement is to build a great Pemalang needed synergy togetherness with all the people. The people are included and highlighted as an important element in building Pemalang Regency. The power of persuasion of this ad is manifested through the phrase "Bersama Rakyat" which can create the nuance of understanding to create an attitude of public support to the candidate.

\section{(2) "HARJO BERSAHABAT, PILIHAN RAKYAT"}

The discourse on this ad provides political educational value to the audience that friendly and close leaders with the people are the leaders of the people's choice. The indicator of a leader's election shown in this ad is the closeness and friendship value of a leader to his people.

(3) "BRAYAN URIP"

The use of Javanese language in this political advertising discourse with the choice of the word 'Brayan Urip' gives insight that in the political contestation of Pilkada and community life, Brayan Urip's meaningful value of togetherness in life is always relevant and a necessity of life for the people. In addition,
Brayan Urip values teach about the treasures of goodness and the glory of life to build mutuality together.

(4) "GUYUB RUKUN MBANGUN KEBUMEN"

The value conveyed in the discourse of this advertisement is the spirit of creating a substantial Guyub Rukun meaningful together build harmony between citizens. The value of harmony is prioritized as an important part of the effort to build Kebumen Regency. This ad can mobilize a power in society to always be in harmony.

\section{(5) "SITHIK OMONGE, AKEH KERJONE"}

Sithik omonge, akeh kerjone is a Javanese terminology meaning that a leader must be able to show performance with a little talk attitude a lot of work. Through this advertisement, the candidates of regents / mayors educate the voters to choose candidates for local leaders who do not have much promise / talkative promise. On the other hand, this candidate wants to show that he can show as a leader who speaks little but works a lot. Based on the data on the advertisement discourse above can be concluded that the elements of phronesis on ethos aspects contained in Pilkada political advertisement Central Java in 2015 is not widely used. The value of political education and insight values that can increase the knowledge of the audience is also still minimum raised in the election discourse, whereas elements of phronesis on the ethos aspect of election is very important as a communication of political education. Communication occurs in all aspects of community life, one of them in the political sphere. Most political activity is communication between political and targeted actors. Communication and politics that converge into political communications essentially talk about speech and influence influence. Political communication is a part of political activity aimed at conveying political-characterized messages by political actors to political goals (Eliya and Ida Zulaeha, 2017: 286). In this context, the self-image of candidates for regional leaders is communicated to the public. According Mardikantoro, 2015: 6), imaging means an effort to highlight the best image in the public eye.

\section{2) Arete}

Arete is the ability to demonstrate his ability to lead that can be felt to create happiness for audiences. The element of arete in the ethos aspect contained in 
political election of 2015 is illustrated through the following discourse.

(1) "TOGETHER BUILD PEKALONGAN, MORE FASTER AND USEFUL."

The discourse of this political advertisement indicates that the candidate pair of Pekalongan Regent number 1 is a candidate of regent who can work faster and more benefit. Sentences used are sentences that convince the audience that this pair candidates is better than other candidates.

(2) "AMANAH LEADER, SMART, AND NOBLE.

Arete elements shown in this election campaign discourse using word choices that indicate the leadership character required by the audience that is trustworthy, intelligent, and noble character. The prospective voters' audience is assured that their future leaders have good character so that they can make people happy.

(3)

"SELF-RELIANT INDEPENDENT"

The choice of the word 'independent' and 'self-reliant' has almost the same meaning that is not dependent on others and able to utilize the potential and strength of himself. Audience audiences are assured that their leaders have the capability of independence and self-reliance.

(4) "SMART AND VIRTOUS."

Smart and virtuous are the two leadership characteristics required by society. Pilkada advertisements with the rhetorical style of this erate model can describe the character of the candidate leaders to be elected in the elections.

"YOUTH, NATIONALIST, AND RELIGIOUS."

The element of arete in the ad discourse number (6) is to lift the character of leadership that is reflected by three types of youth, nationalist, and religious.

3) Eunoia

Eunoia is goodwill, similar to the commitment of self to do the best for others / the public. Through political election of Pilkada, candidates of local leaders convey code about their vision and aspirations if elected as regional leaders to provide the best for the community. According to Rokhman (2013: 2-3) states that speakers are required to choose the language code appropriately so that communication can take place smoothly and reasonable. The selection is not random but determined by various factors, such as social, cultural, and situational factors. The element of eunoia in the ethos aspect contained in political election of 2015 election is illustrated through the following discourse.

(1) "ONE FOR CHANGE, AMANAH AND RAHMATAN LIL ALAMIN"

The use of the word 'one' in the sentence (1) refers to the serial number of the candidate, serial number one. One means a double one as a serial number and one as a unifying word for a change. The word 'amanah' is a characteristic of leadership that is highlighted to the public that the candidate of regent has the character of credibility or can be trusted to be the leader who guard all. In the context of this guard, political advertising Pilkada raised terminology 'rahmatan lil alamin' which is a mercy for the universe.

(2) "LEADER WHO SERVES AND PRPTECT."

Political advertisement made by candidate of Surakarta Mayor number 2 of Surakarta City FX Hadi RudyatmoAchmad Purnomo who chose sentence "Leader who Serves and Protects". The simplicity of word choice directs the voting audience to the aspect that the people need to have a leader who can serve and nurture their people.

(3) "PROSPERO, RELIGIUS, PROGRESS"

The choice of the phrase "Prosperous, Religious, Progress" implies a change or movement to a better state that is in the form of a driving force of change movement toward prosperous, religious, and progressive Pekalongan Regency.

In the ethos aspect, the characteristics of election advertisements are in the form of public education, the good personality of the candidate, and the public trust towards the future leader.

\section{Pathos}

Aspect of pathos on the Pilkada political advertising discourse refers to an aspect that shows that political advertising is able to touch the hearts of audiences, feelings, emotions, hopes, and sympathy or affection. This is also known as emotional appeal. Pathos also serves as a form of driving force for the alteration and generating of emotions (Aristotle in Maarif, 2015: 25-27). 
Here are the forms of political election discourse based on rhetorical approach that meets aspects of pathos.

a) Touch the hearts of the audience

Together continue to build Grobogan; Wonosobo is cool, creative, prosperous, and harmonious; Work wholeheartedly; For the people of Demak more prosperous; Wonge dewe, wonge tulus, wonge dibutuhke;

b) Feelings of emotion, hope and emotional appeals

Change is more prosperous; Time for independent lead;

c) Motivated propulsion and emotional generator

Let's carve history, we born the original leader from the people; rise to work, together we can; Be Self-reliant Independent

\section{Logos}

Logos aspect of political election discourse refers to an aspect which indicates that the political advertisement presented by candidate regent / mayor pairs containing the power of influence is accompanied by reasons, and it makes sense, contains logical proof, or appears as evidence.

According to Aristotle (in Maarif, 2015) stated that logos in the perspective of rhetoric is a format of messages made and delivered by orators to persuade audiences. The format consists of three forms of parables, proverbs, and rhetorical arguments. Here are the forms of political election discourse based on rhetorical approach that meets aspects of logos.

a. Pemimpine kerjo, rakyate rejo

b. Rise to work, together we can

c. Harjo be friends, people's choice.

\section{Conclusion}

Based on the discussion above it can be concluded that the characteristics of political discourse of Pilkada based on the rethoric study are in the form of ethos, pathos, and logos. In the ethos aspect, the characteristics of election advertisement are in the form of educational techniques to the public, the good personality of the candidate, and the public credibility towards the candidate of leader. In the aspect of the pathos there are characteristics of empathy, sympathy, motivation of change, emotion generating, while in the logos aspect manifested in the discourse of persuasion logically, and the use of the words parables and proverbs.

The results of this study can be used as teaching materials in Indonesian language learning in schools on the basic competencies of writing advertisements and slogans and interpreting advertising messages.

\section{References}

Abidin, Yusuf Zaenal. (2013). Pengantar Retorika. Bandung: Pustaka Setia

Eliya, Ixsir dan I. Zulaeha. (2017). Pola Komunikasi Politik Ganjar Pranowo dalam Perspektif Sosiolinguistik di Media Sosial Instagram. Jurnal Seloka edisi 6 (3) 2017: Universitas Negeri Semarang.

Firmanzah. 2007. Marketing Politik: Antara Pemahman dan Realitas. Obor: Jakarta.

Herrick, James A. The History and Theory of Rhetoric An Introduction. Chapter One : An Overview of Rhetoric. Boston : Pearson Education.

Keraf, Gorys. (2010). Argumentasi dan Narasi. Jakarta: Gramedia

Mardikantoro, Hari Bakti. (2014). Pembentukan Reputasi Calon Presiden 2014 Dalam Berita Di Media Massa Online : Kajian Wacana Kritis.

Rakhmat, Jalaludin. (2008). Psikologi Komunikasi. Bandung: Rosda Karya.

Rokhman, Fathur. (2013). Sosiolinguistik: Suatu Pendekatan Pembelajaran Bahasa dalam Masyarakat Multikultural. Yogyakarta: Graha Ilmu.

Tabroni, Roni. (2014). Marketing Politik; Media dan Pencitraan di Era Multipartai. Yogyakarta: Graha Ilmu.

Widyawari, Caecilia Petra Gading May dan I. Zulaeha. (2016). Representasi Idiologi dalam Tuturan Santun para Pejabat Negara pada Talk Show Mata Najwa. Jurnal Seloka edisi 5(1). Universitas Negeri Semarang. 